„Logopedia Silesiana”, t. 9, ISSN 2391-4297

https://doi.org/10.31261/LOGOPEDIASILESIANA.2020.09.06

pp. 1-10: English language version; pp. 11-21: Polish language version

(cc) BY-SA

\title{
Katarzyna GodlewsKa
}

Graduate of general and clinical speech therapy, First Faculty of Medicine,

Medical University of Warsaw

(D) https://orcid.org/0000-0002-0266-8069

BARBARA JAMRÓZ

Department of Otorhinolaryngology, Head and Neck Surgery, Medical University of Warsaw

(D) https://orcid.org/0000-0002-0127-0139

JoAnna ChMielewsKa-WALCZAK

Department of Otorhinolaryngology, Head and Neck Surgery, Medical University of Warsaw

(D) https://orcid.org/0000-0002-0962-8131

Magdalena Milewska

Department of Clinical Dietetics, Medical University of Warsaw

(D) https://orcid.org/0000-0001-9990-1578

\section{Assessment of the functioning of patients with dysphagia after total laryngectomy}

Aвstract: The aim of the study was to evaluate the functioning of patients with swallowing disorders after total laryngectomy. The study initially included 20 patients who were more than 6 months after total laryngectomy, requiring videofluoroscopy (VFSS) due to reported dysphagia. The final group consisted of 10 people ( 8 men and 2 women). The examination procedure included conducting an interview, performing a full VFSS examination and completing the MDADI questionnaire by the patient. The most common problems found in the group were the lack of contact of the base of tongue with the posterior wall of the throat, disturbances in bolus formation and pumping movements of the tongue. The patients assessed their quality of life as low. The presence or absence of nasal food regurgitation significantly influenced the functioning of patients. Patients' reports of swallowing disorders and problems with the production of voice and substitute speech are indications for further diagnosis (e.g. VFSS). The choice of an effective therapeutic method may improve the quality of life of these people.

KEYwORDs: total laryngectomy, quality of life, VFSS, MDADI

Ocena funkcjonowania chorych z zaburzeniami połykania po operacji radykalnego usunięcia krtani

STRESZCZENIE: Celem pracy była ocena funkcjonowania chorych z zaburzeniami połykania po operacji radykalnego usunięcia krtani. Do badania wstępnie zakwalifikowano 20 pacjentów, będących dłużej niż 6 miesięcy po całkowitym usunięciu krtani, wymagających przeprowadzenia badania wideofluoroskopowego (VFSS) ze względu na zgłaszane zaburzenia połykania. Grupę ostateczną stanowiło 10 osób (8 mężczyzn i 2 kobiety). Procedura badania obejmowała: zebranie wywiadu, wykonania pełnego badania VFSS oraz wypełnienie przez pacjenta kwestionariusza MDADI. Naj- 
częściej stwierdzanymi problemami były: brak kontaktu nasady języka z tylną ścianą gardła, zaburzenia obróbki oralnej kęsa oraz ruchy pompujące języka. Chorzy oceniali nisko swoją jakość życia. Obecność lub brak regurgitacji treści pokarmowych do nosa znacznie wpływał na funkcjonowanie pacjentów. Zgłaszanie przez chorych zaburzeń połykania oraz problemów z wytworzeniem głosu i mowy zastępczej jest wskazaniem do dalszej diagnostyki (np. VFSS). Dobór skutecznej metody terapeutycznej może wpłynąć na poprawę jakości życia tych osób.

SŁOWA KLUCzowe: laryngektomia całkowita, jakość życia, VFSS, MDADI

The complete removal of a larynx causes significant changes in a patient's life. Swallowing disorders, which also affect social functioning, are an important part of it. Dysphagia in patients with head and neck cancers is an important issue. Even two-thirds of the patients are confronted with it. The data below show the scale of the problem among the patients with head and neck cancers (Stręk et al., 2005, pp. 142-146, Landera, Lundy \& Sullivan, 2010, pp. 39-44, Stręk et al., 2006, pp. 98-105, Hamerlinska A et al., 2018, pp. 86-103).

The majority of patients after radical laryngeal removal complain about the difficulty in swallowing (up to $72 \%$ ), which forces them to change the consistency of their food and, consequently, to change their current diet (Terlingen, Pilz, Kuijer, Kremer \& Baijens, 2018, pp. e2733-e 2748; Stoner, Fullerton, Freeman, Chheda \& Estores, 2019, pp. el-e9; Lippert et al., 2016, pp. e541-e549; Zhang et al. 2016, pp. e295-e302; Búa, Pendletonc, Westinb \& Rydellc, 2018, pp. el70-e174). The cause of the disorders include: anatomical changes affecting the tongue's mobility and the mechanism of opening the upper esophageal sphincter (one of the elements of opening the upper esophageal sphincter is the forward and upward movement of the larynx and the hyoid bone), the "post-operative shape," which might be the cause of the "pseudo diverticulum" at the throat level. Moreover, we might distinguish: the shape of the "pseudo diverticulum," which may cause the bolus to deposit at the level of the throat, the cricopharyngeal muscle and the weakening of the throat muscle contraction, which may cause food deposits and their regurgitation from the middle throat to the mouth or the nasopharynx. Rarely, in case of about $10 \%$ of patients, the cause of dysphagia is given as a skinpharyngeal fistula and excessive tension of the neck muscles.

The additional severity of the symptoms may be the result of complementary radiotherapy. It is mainly associated with the appearance of soft tissue swelling in the head and neck, swallowing pain, xerostomia, olfactory and taste disorders and late complications, such as: mandibular or jaw necrosis, degenerative changes in the temporomandibular joints or damage to salivary glands (Czerżyńska, Orłow \& Choromańska, 2017, pp. 53-62; Stręk et al., 2003, pp. 120-125; Hutcheson et al., 2012, pp. e5793-e5799). 
To date, no results of studies on the occurrence of swallowing disorders in the Polish population in people after radical laryngeal resection, using instrumental studies showing the mechanism of the disorder and its impact on the quality of life, have been published.

\section{Material and methods}

Originally, a group of 20 people after complete laryngectomy, qualified for videofluoroscopic examination by a phoniatrician or speech therapist due to the reported difficulties in swallowing food or increased difficulty in producing a substitute voice was included in the study. Finally, 10 people were excluded from it for the following reasons: the death of a patient, development of other diseases affecting swallowing disorders (e.g. stroke), progression of the underlying disease and the need for further surgical interventions, or the inability to perform the full examination procedure due to the failure of the videofluoroscopic equipment. The inclusion criteria were as follows: the condition after complete removal of a larynx, the minimum period of 6 months after the surgery, the presence of clinical indications to perform an instrumental diagnosis of oropharyngeal dysphagia (VFSS) based on phoniatrical and speech therapy evaluation, the patient's consent to participate in the examination. Ultimately, the study group consisted of 10 consecutive patients meeting the criteria, reporting to the Department of Otorhinolaryngology, Head and Neck Surgery of the University Clinical Centre of the Medical University of Warsaw from April 2017 to June 2018. The average age of the subjects was $65,5 \pm 5,3$ years. The youngest person was 56 and the oldest -75 . The study involved 8 men $(80 \%)$ and 2 women (20\%).

All patients were examined according to a uniform protocol: 1) an interview including questions regarding the biometric data (age, gender), method of treatment (surgery, radiotherapy), type of substitute voice generated; 2) videofluoroscopic examination with diagnostic and therapeutic part (VFSS); 3) filling in a MDADI (M.D. Aderson Dysphagia Inventory) questionnaire with the use of paper-centers.

The VFSS examination was performed on an Opera, rate 3 frames per second camera. In the introductory part, the anatomy of the structures of the oral cavity and throat was evaluated. Next, the patients took $5 \mathrm{ml}$ of water mixed with barite (1:1 ratio), held it in their mouths and swallowed it only at the command (oral control evaluation). Later, the intake of concentrated liquid (water: barite $=$ 1:1, Nulilis Clear thickener, 1 scoop per $200 \mathrm{ml}$ of liquid) and solid food (baritelubricated dry matter) was evaluated. Independently, two different persons with 
five-year experience in carrying out and describing the VFSS tests (a phoniatrician and speech therapist), evaluated the following parameters: the contact of a tongue base with the back wall of the throat, the abnormalities in oral processing, the occurrence of pumping movements of the tongue, the presence of nasal nutrient regurgitation, the presence of cricopharyngeal bar. Finally, the effectiveness of therapeutic procedures was checked.

After the completion of the VFSS study, the patients filled in the MDADI questionnaire. The survey is used to assess the quality of life associated with swallowing disorders in oncological patients. The questionnaire contains 20 questions, scored on a scale of 1-5; she overall score might range between 0 and 100 points. The higher number of points, the better quality of life associated with swallowing disorders.

The statistical analysis was performed using IBM SPSS Statistics 25 package. The program was used to characterise the group. In the statistical analysis of the results a frequency analysis was performed (N, \%). Due to the small size of the group, descriptive statistics were used in the study.

The Bioethics Committee (AKEB/225/2018) has given its consent to conduct this study. The study was conducted as a part of the thesis under the same title by the first author;the second author was the supervisor.

\section{Results}

In most patients, the surgical treatment was supplemented by radiotherapy $(\mathrm{n}=7$, $70 \%)$. Oesophageal voice was developed by 3 patients (30\%), while the remaining 7 people (70\%) used an oropharyngeal pseudo-pharyngeal whisper. Two people had a Provox vocal prosthesis implanted.

The results of videofluoroscopic examination are shown in Table 1 and Figs. 1-2. Oral (abnormal bolus formation, pumping movements of the tongue) and pharyngeal (cricopharyngeal bar, nasal regurgitation, disturbed contact of the tongue base with the posterior pharyngeal wall) phases of swallowing were found. The results obtained in the MDADI questionnaire are shown in Table 2, and the comparison of subgroups due to the treatment method used (surgery vs. surgery with complementary radiotherapy) - in Figure 1. The patients after radiotherapy reported worse quality of life than those without complementary treatment. This affected emotional, functional, and social spheres of life, and general evaluation.

The highest results in the overall assessment were obtained in the people who did not show any cricopharyngeal bar $(n=3)$, nasal regurgitation $(n=2)$ or pumping movements of the tongue $(\mathrm{n}=2)$ (the highest results in this part of the questionnaire: 80, 60, 40); for the functional assessment - similar parameters from the VFSS test 
K. Godlewska, B. Jamróz, J. Chmielewska-Walczak, M. Milewska: Assessment...

TABLE 1. The evaluation of the results of selected parameters of the videofluoroscopic swallowing study

\begin{tabular}{|l|c|c|}
\hline \multicolumn{1}{|c|}{ Test parameter VFSS } & Pathology [\%] & Standard [\%] \\
\hline $\begin{array}{l}\text { Contact between the tongue base and the poste- } \\
\text { rior pharyngeal wall }\end{array}$ & 100 & - \\
\hline Oral bolus control & 90 & 20 \\
\hline Tongue pumping movements & 80 & 40 \\
\hline Cricopharyngeal bar & 60 & 70 \\
\hline Nasal regurgitation & 30 & 10 \\
\hline
\end{tabular}

SOURCE: Own study.

TABLE 2. Results of the MDADI questionnaire

\begin{tabular}{|l|c|c|c|c|}
\hline \multicolumn{1}{|c|}{ Value } & $\begin{array}{c}\text { General } \\
\text { assessment }\end{array}$ & $\begin{array}{c}\text { Emotional } \\
\text { disorders }\end{array}$ & $\begin{array}{c}\text { Functional } \\
\text { disorders }\end{array}$ & Social disorders \\
\hline Average \pm SD & $32,0 \pm 21,5$ & $45,7 \pm 14,5$ & $52,5 \pm 12,6$ & $45,4 \pm 9,9$ \\
\hline $\begin{array}{l}\text { Median } \\
\text { (min.-max.) }\end{array}$ & $\begin{array}{c}20 \\
(20-80)\end{array}$ & $\begin{array}{c}41,5 \\
(33-83)\end{array}$ & $\begin{array}{c}48 \\
(40-84)\end{array}$ & $\begin{array}{c}44,5 \\
(25-58)\end{array}$ \\
\hline
\end{tabular}

SOURCE: Own study.

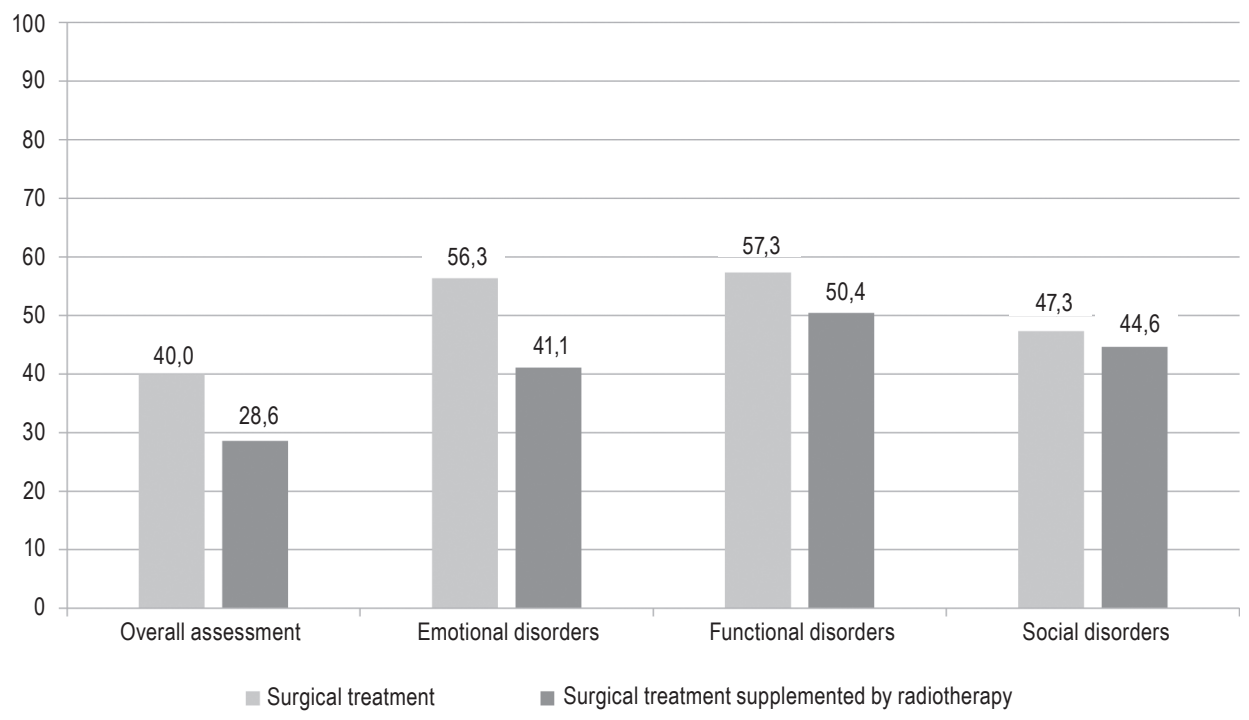

GRAPH 1. The subjective assessment of the quality of life in the study group due to the treatment applied (surgery vs. surgery with complementary radiotherapy)

SOURCE: Own study.

proved to be undisturbed: no cricopharyngeal muscle spasm $(\mathrm{n}=2)$, nasal regurgitation $(n=3)$ and tongue pumping movements $(n=1)$ (highest results in this part of the questionnaire: $49,53,83$ ); for functional evaluation: no cricopharyngeal 
muscle contraction $(\mathrm{n}=2)$, nasal regurgitation $(\mathrm{n}=3)$ (highest results in this part of the questionnaire: $84,59,56,55)$; and for functional evaluation: no nasal regurgitation $(n=2)$ and cricopharygeal muscle contraction $(n=1)$ (highest results in this part of the questionnaire: 58,57,55). The most important parameters associated with better quality of life assessment turned out to be: functional shape at the level of the oropharynx and hypopharyngx segment and the related presence or lack of nasal regurgitation.

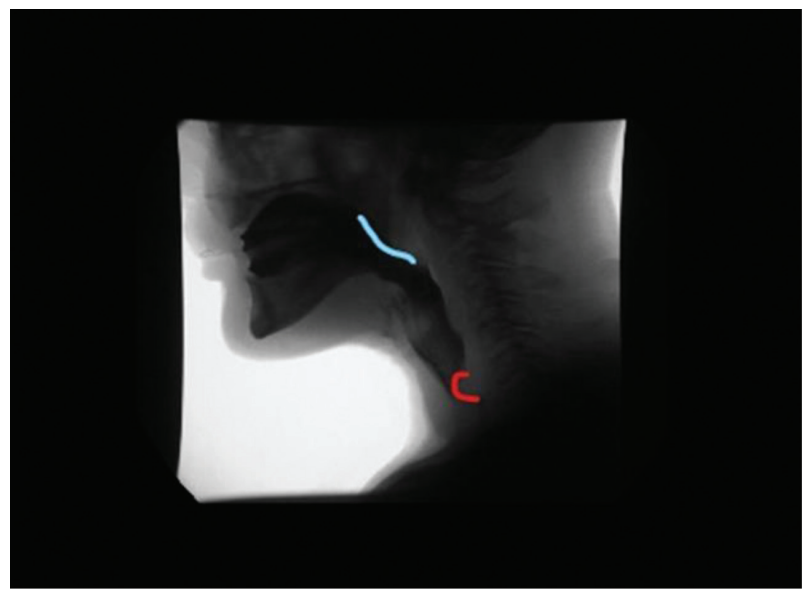

FiguRE 1. No contact of the tongue with the posterior pharyngeal wall (blue line) and a cricopharyngeal bar (red line)

Source: Own study. Study performed in the Department of Otorhinolaryngology, Head and Neck Surgery, Medical University of Warsaw.

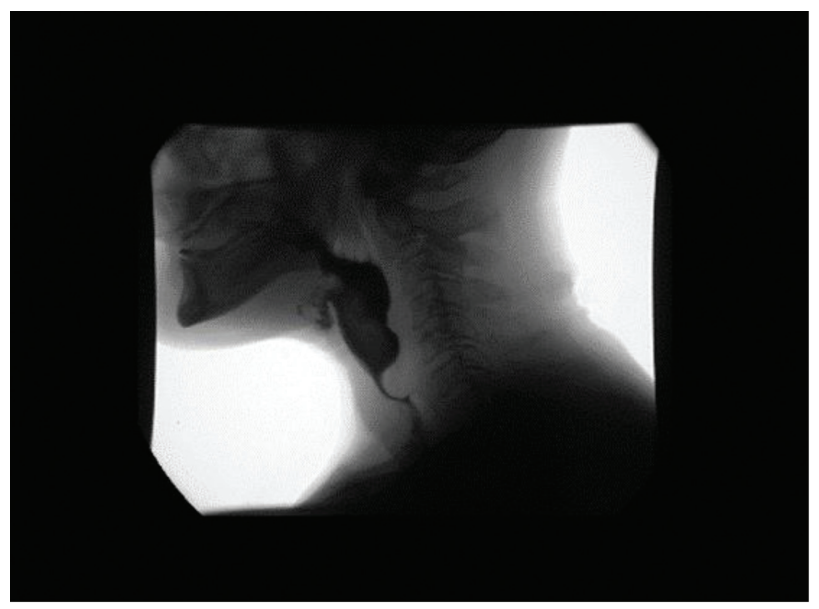

FIGURE 2. Cricopharyngeal bar, massive residue over the upper esophageal sphincter, risk of nasal regurgitation

Source: Own study. Study performed in the Department of Otorhinolaryngology, Head and Neck Surgery, Medical University of Warsaw. 


\section{Discussion}

The patients after a radical laryngeal removal, since the moment of diagnosis, have been facing many difficulties in their daily lives. The operation has serious consequences leaving a visible trace in the emotional and functional life of patients.

This applies not only to the way the substitute voice is created, but also to the physiology of swallowing. Therefore, it is very important to choose an appropriate therapeutic plan, taking aspects relevant to the quality of life into account.

Moreover, the literature describes the relationship between the use of radiotherapy as a complementary method and the quality of life of patients (Hutcheson et al. 2012, pp. e5793-e5799). In this study, 70\% of the group were patients who had this form of treatment applied. The causes of swallowing disorders in patients after radiotherapy may be: xerostomia, which negatively affects bolus formation and oral transport; increased swelling and soreness of soft tissues of the head and neck; nausea, dentition problems, appetite loss, dehydration and neuropathy within the afferent fibers (Terlingen et al., pp. e2733-e2748; Czerżyńska et al., 2017, pp. 53-62; Búa et al., 2018, pp. el70-e174). In the study group, as many as $90 \%$ of the patients had a problem with the bolus formation, and $80 \%$ of the patients had concurrent tongue pumping movements, which may indicate a problem with triggering the reflex to swallow. Following the meta-analysis, Terlingen et al. (2018, pp. e2733-e2748), highlight the negative impact of adjuvant radiochemical therapy on the swallowing mechanism and quality of life of patients after a complete laryngectomy. Negative effects are observed both before and after the treatment, as even $89 \%$ of patients are affected. Usually, the symptoms are more severe when swallowing solid foods than when swallowing fluids (feeling of residue, having to swallow several times, dryness).

Sweeny, Golden, White, Magnuson, Carroll and Rosenthal (2012, pp. e395e402) emphasise that complementary treatment does not affect the occurrence of cricopharryngeal muscle contraction. This muscle plays an important role both during swallowing; it is a functional element of the upper esophageal sphincter (UES), and, during the learning of the substitute voice, it is an element of the pseudo-glottis (Landera et al., 2010, pp. 39-44). In the present study, during videofluoroscopic examination, cricopharyngeal muscle contraction was noted in $60 \%$ of patients and the problem with the creation of subtitiut voice was noted in $70 \%$ of patients who communicated by means of an oropharyngeal pseudowhisper. In addition, residue over UES may cause nasal regurgitation (30\% of patients examined). Terlingen and co-authors (2018, pp. e2733-e 2748), have shown that cricopharyngeal contraction is the cause of dysphagia in about $22-36 \%$ of patients, and stenosis at the site of the pharyngo-oesophageal segment in about $15-19 \%$ of patients. Búa et al. (2018, pp. el70-el74) also emphasise the importance of the 
pharyngo-oesophageal complex both for the production of the substitute voice and for swallowing. Disorders in this area will affect both functions, which is often forgotten in everyday medical and speech therapy practice. The authors emphasise that the most common therapeutic method in this case is endoscopic dilatation, although botulinum toxin injection (effectiveness about 10-60\%) is also used in practice (Terlingen et al., 2018, pp. e2733-e 2748, Búa et al., 2018, pp. el70-e174). According to Stoner and co-authors (2019, pp. el-e9), the majority of constrictions are observed during the first year after laryngectomy - up to $80 \%$, and the most sever problem is in those patients that require a minimum of 5 dilatation treatments and include light below $14 \mathrm{~mm}$.

The VFSS examination revealed the abnormal contact of the tongue base with the posterior pharyngeal wall in all patients. Disturbed mobility of the tongue may result not only from the scope of the surgery itself, but also from stiffening of tissues after the supplementary treatment. The lack of contact between the base of the tongue and the posterior pharyngeal wall may in turn cause difficulties in releasing the reflex to swallow and the occurrence of movements pumping the tongue ( $80 \%$ of patients in this group).

A study of the quality of life of the patients after total laryngectomy accompanied by dysphagia showed that its overall assessment is low. On average, the patients received 32.0/100 points. Comparably, few patients assessed social and emotional disorders. The best results were obtained in the functional sphere (52.5/100 points). The results presented above indicate a very big problem in patients' functioning in everyday life. Emotional, functional, and social disorders are of the results of base laryngeal removal. This may be the cause of low self-esteem, creating distance, no enjoyment of eating, limiting social contacts (Studzińska, Obrębowski, Wiskirska-Woźnica \& Obrębowska, 2012, pp. 124-128). A meta-analysis of Terlingen et al. (2018, pp. e2733-e2748) has shown that psychotherapy is an important method of supporting patient treatment. The greatest benefits, in the first year after the procedure, were enjoyed by the patients who attended meetings of "patient-patient"support groups, smaller benefits were achieved by "doctor-patient" support groups, and the greatest problems were reported by the patients not participating in a therapeutic group at all. The authors emphasise, however, that one validated questionnaire dedicated to the patients after laryngectomy is missing. Available questionnaires (such as MDADI, Swallow Quality of Life) contain questions that cannot be included in this group of patients due to the anatomical changes resulting from the operation. The authors of this study have similar insights.

It is worth noting that dysphagia is one of the possible causes of malnutrition and dehydration, causing unintended weight loss (lack of safety and effectiveness of swallowing). Additionally, it may be accompanied by depression or affecting the low quality of life in these people (Stręk et al., 2005, pp. 142-146). The results 
of the MDADI questionnaire showed that patients who underwent adjuvant radiotherapy, which concerned all spheres of life - emotional, social and functional ones - had lower quality of life. This is probably due to the overlap of radiation changes with postoperative changes. The MDADI questionnaire is a tool used to evaluate the quality of life of oncological patients (Chen, Frankowski \& BishopLeone, 2001, pp. e870-e876). It makes monitoring of changes before and after the application of therapeutic techniques possible, but leaves a certain lack of satisfaction due to the fact that not all questions are adequate for the patients after total laryngectomy (e.g. questions about coughing while drinking fluids).

It is, therefore, understandable that patients after radical laryngectomy will not feel completely healthy and that the process of self-acceptance after the therapy can be long, as it is affected by a number of changes brought not only by the surgery, but also by the complementary treatment. These patients require help from a multidisciplinary team (laryngologist, radiotherapist, phoniatrician, speech therapist, dietician, psychologist).

\section{Summary}

This study has shown that in patients with dysphagia after surgery for total laryngeal removal, attention should be paid to the co-occurrence of problems with the production of a substitut voice and symptoms of dysphagia. In view of the presented results, the recommendations of the British Society of Speech Therapists concerning the indication of VFSS in patients after total laryngectomy seem to be correct, as emphasized by Chmielewska, Jamróz, Gibiński, Sielska-Badurek, Milewska and Niemczyk (2017, pp. 2-20). The performance of VFSS will allow to assess the mechanism of the disorder and to choose an appropriate method of rehabilitation and monitor its progress. A Polish questionnaire for videofluoroscopic evaluation is now available for patients after total laryngectomy (Jamróz, Chmielewska-Walczak \& Milewska, 2019, pp. 134-136). It is worth noting that the reported problems affect the quality of life of patients, which also correlates with the treatment method used (combined vs. surgical treatment only). 


\section{References}

Búa, B.A., Pendletonc, H., Westinb, U., \& Rydellc, R. (2018). Voice and swallowing after total laryngectomy. Acta Oto-Laryngologica, 138(2), el70-e174.

Chen, A., Frankowski, R., \& Bishop-Leone, J. (2001). The development and validation of a dysphagia-specific quality of life questionnaire for patients with head and neck cancer. Archives of Otolaryngology-Head \& Neck Surgery, 127, e870-e876.

Chmielewska, J., Jamróz, B., Gibiński, K., Sielska-Badurek, E., Milewska, M., \& Niemczyk, K. (2017). Badanie wideofluoroskopowe - procedura badania z oceną kwestionariuszową. Polski Przegląd Otorynolaryngologiczny, 6(1), 2-20.

CZerżyńska, M., OrŁow, P., \& Choromańska, M. (2017). Skutki uboczne radioterapii nowotworów głowy i szyi. Metody leczenia odczynów popromiennych w jamie ustnej. Pediatria i Medycyna Rodzinna, 13(1), 53-62.

HAMERLińkA, A., \& LEMAŃCZYK, M. (2018). Dysfagia nowotworowa w trakcie radioterapii na przykładzie osób po usunięciu krtani - wyniki badań własnych. Neurolingwistyka Praktyczna, 4, 86-103.

Hutcheson, K., et al. (2012). Late dysphagia after radiotherapy-based treatment of head and neck cancer. Cancer, 118(23), e5793-e5799.

Jamróz, B., Chmielewska-Walczak, J., \& Milewska, M. (2019). Instrumentalne metody badania zaburzeń połykania. Atlas z materiałem wideo. Warszawa: Medyk.

Landera, M., Lundy, D., \& Sullivan, P. (2010). Dysphagia after total laryngectomy. American Speech-Language-Hearning Association, 19(2), 39-44.

LIPPERT, D., et al. (2016). Preliminary evaluation of functional swallow after total laryngectomy using high-resolution manometry. Annals of Otology, Rhinology \& Laryngology, 125(7), e541-e549.

Manikantan, K., et al. (2009). Dysphagia in head and neck cancer. Cancer Treatment Reviews, 35, e724-e732.

Stoner, P.L., Fullerton, A.L., Freeman, A.M., Chheda, N.N., \& Estores, D.S. (2019). Endoscopic dilation of refractory postlaryngectomy strictures: A case series and literature review. Gastroenterology Research and Practice, e1-e9, https://doi.org/10.1155/2019/8905615.

STRĘK, P., et al. (2003). Ankietowa samoocena zaburzeń połykania i jakość życia u chorych leczonych z powodu nowotworów głowy i szyi. Otorynolaryngologia, 2(3), 120-125.

STRĘK, P., et al. (2005). Jakość życia a dysfagia u chorych po operacji raka krtani. Otorynolaryngologia, 4(3), 142-146.

STRĘK, P., et al.. (2006). Wpływ podeszłego wieku na subiektywne oceniane zaburzenia połykania u chorych leczonych z powodu nowotworów głowy i szyi. Gerontologia Polska, 14(1), 98-105.

Studzińska, K., Obręвowski, A., Wiskirska-Woźnica, B., \& Obrębowska, Z. (2012). Problemy psychologiczne w rehabilitacji chorych po operacjach całkowitego usunięcia krtani. Polski Przegląd Otorynolaryngologiczny, 2(1), 124-128.

Sweeny, L., Golden, J.B., White, H.N., Magnuson, J.C., Carroll, W.R., \& Rosenthal, E.L. (2012). Incidence and outcomes of stricture formation postlaryngectomy. Otolaryngology - Head and Neck Surgery, 146(3), e395-e402.

Terlingen, L.T., Pilz, W., Kuijer, M., Kremer, B., \& Baijens, L.W. (2018). Diagnosis and treatment of oropharyngeal dysphagia after total laryngectomy with or without pharyngoesophageal reconstruction: systematic review. Head \& Neck, 40, e2733-e2748.

ZHANG, T., et al. (2016). Biomechanics of pharyngeal deglutitive function following total laryngectomy.Otolaryngology - Head and Neck Surgery, 155(2), e295-e302. 
„Logopedia Silesiana”, t. 9, ISSN 2391-4297

https://doi.org/10.31261/LOGOPEDIASILESIANA.2020.09.06

s. 1-10: wersja angielskojęzyczna; s. 11-21: wersja polskojęzyczna

\title{
(cc) BY-SA
}

\section{KATARZYNA GodLEWSKA}

Absolwentka logopedii ogólnej i klinicznej, I Wydział Lekarski,

Warszawski Uniwersytet Medyczny

(D) https://orcid.org/0000-0002-0266-8069

\section{BARBARA JAMRÓZ}

Klinika Otorynolaryngologii, Chirurgii Głowy i Szyi, Warszawski Uniwersytet Medyczny

(D) https://orcid.org/0000-0002-0127-0139

JoAnNa ChMielewsKa-WALCZAK

Klinika Otorynolaryngologii, Chirurgii Głowy i Szyi, Warszawski Uniwersytet Medyczny

(D) https://orcid.org/0000-0002-0962-8131

Magdalena MilewsKa

Zakład Dietetyki Klinicznej, Warszawski Uniwersytet Medyczny

(D) https://orcid.org/0000-0001-9990-1578

\section{Ocena funkcjonowania chorych z zaburzeniami połykania po operacji radykalnego usunięcia krtani}

\begin{abstract}
Assessment of functioning of patients with dysphagia after total laryngectomy
Авsтract: The aim of the study was to evaluate the functioning of patients with swallowing disorders after total laryngectomy. The study initially included 20 patients who were more than 6 months after total laryngectomy, requiring videofluoroscopy (VFSS) due to reported dysphagia. The final group consisted of 10 people ( 8 men and 2 women). The examination procedure included conducting an interview, performing a full VFSS examination and completing the MDADI questionnaire by the patient. The most common problems found in the group were the lack of contact of the root of the tongue with the back wall of the throat, disturbances in the oral processing of a piece of food and pumping movements of the tongue. The patients assessed their quality of life as low. The presence or absence of nasal food regurgitation significantly influenced the functioning of patients. Patients' reports of swallowing disorders and problems with the production of voice and substitute speech are indications for further diagnosis (e.g. VFSS). The choice of an effective therapeutic method may improve the quality of life of these people.
\end{abstract}

KEYwORDs: total laryngectomy, quality of life, VFSS, MDADI

STRESZCZENIE: Celem pracy była ocena funkcjonowania chorych z zaburzeniami połykania po operacji radykalnego usunięcia krtani. Do badania wstępnie zakwalifikowano 20 pacjentów, będących dłużej niż 6 miesięcy po całkowitym usunięciu krtani, wymagających przeprowadzenia badania wideofluoroskopowego (VFSS) ze względu na zgłaszane zaburzenia połykania. Grupę ostateczną stanowiło 10 osób (8 mężczyzn i 2 kobiety). Procedura badania obejmowała: zebranie wywiadu, wykonania pełnego badania VFSS oraz wypełnienie przez pacjenta kwestionariusza MDADI. Naj- 
częściej stwierdzanymi problemami były: brak kontaktu nasady języka z tylną ścianą gardła, zaburzenia obróbki oralnej kęsa oraz ruchy pompujące języka. Chorzy oceniali nisko swoją jakość życia. Obecność lub brak regurgitacji treści pokarmowych do nosa znacznie wpływały na funkcjonowanie pacjentów. Zgłaszanie przez chorych zaburzeń połykania oraz problemów z wytworzeniem głosu i mowy zastępczej jest wskazaniem do dalszej diagnostyki (np. VFSS). Dobór skutecznej metody terapeutycznej może wpłynąć na poprawę jakości życia tych osób.

SŁOWA KLUCzowE: laryngektomia całkowita, jakość życia, VFSS, MDADI

Całkowite usunięcie krtani powoduje znaczne zmiany w życiu pacjenta. Istotne miejsce wśród nich stanowią zaburzenia połykania, które wpływają także na funkcjonowanie społeczne. Dysfagia u chorych z nowotworami w obrębie głowy i szyi jest istotnym zagadnieniem. Mierzy się z nią nawet $2 / 3$ chorych. Statystyka ta uwidacznia, jak duża jest skala problemu wśród chorych z nowotworami w obrębie głowy i szyi (Stręk i in., 2005, s. 142-146; Landera, Lundy, Sullivan, 2010, s. 39-44; Stręk i in., 2006, s. 98-105; Hamerlińska, Lemańczyk, 2018, s. 86-103).

Większość pacjentów po radyklanym usunięciu krtani (nawet 72\%) skarży się na trudności w połykaniu, co zmusza ich do zmiany w zakresie konsystencji pokarmów, a w konsekwencji - zmiany dotychczasowej diety (Terlingen, Pilz, Kuijer, Kremer, Baijens, 2018, s. e2733-e2748; Stoner, Fullerton, Freeman, Estores, 2019, s. e1-e9; Lippert i in., 2016, s. e541-e549; Zhang i in., 2016, s. e295e302; Búa, Pendletonc, Westinb, Rydellc, 2018, s. el70-e174). Przyczyną zaburzeń są m.in.: zmiany anatomiczne, wpływające na zaburzenie ruchomości języka oraz mechanizmu otwarcia górnego zwieracza przełyku (jednym z elementów otwarcia górnego zwieracza przełyku jest ruch krtani i kości gnykowej do przodu oraz do góry), kształt „loży pooperacyjnej”, która może być przyczyną zalegania bolusa na poziomie gardła (tzw. pseudouchyłek gardła), skurcz mięśnia pierścienno-gardłowego oraz osłabienie kontrakcji mięśni gardła, które może powodować zalegania pokarmu i ich regurgitacje z gardła środkowego do jamy ustnej lub do nosogardła. Rzadziej, bo w przypadku około $10 \%$ pacjentów, jako przyczynę dysfagii podaje się powstanie przetoki skórno-gardłowej i nadmierne napięcie mięśni szyi.

Dodatkowe nasilenie dolegliwości może wynikać z uzupełniającej radioterapii. Wiąże się to głównie $\mathrm{z}$ wystąpieniem: obrzęków tkanek miękkich w obrębie głowy i szyi, bólu podczas przełykania, kserostomii, zaburzeń węchu i smaku oraz powikłań późnych, jak martwica żuchwy lub szczęki, zmiany zwyrodnieniowe stawów skroniowo-żuchwowych czy też uszkodzenia ślinianek (Czerżyńska, Orłow, Choromańska, 2017, s. 53-62; Stręk i in., 2003, s. 120-125; Hutcheson i in., 2012, s. e5793-e5799). 
Do tej pory nie opublikowano wyników badań dotyczących występowania zaburzeń połykania w polskiej populacji u osób po radyklanym usunięciu krtani, z wykorzystaniem badań instrumentalnych, pokazujących mechanizm zaburzenia oraz ich wpływu na jakość życia chorych.

\section{Materiał i metody}

Pierwotnie do badania włączono grupę 20 osób po zabiegu larygektomii całkowitej, zakwalifikowanych przez foniatrę lub logopedę do badania wideofluoroskopowego (VFSS) ze względu na zgłaszane trudności w połykaniu pokarmów lub nasilone trudności $\mathrm{z}$ wytworzeniem głosu zastępczego. Finalnie $\mathrm{z}$ badania wyłączono 10 osób, z powodów: śmierci pacjenta, rozwoju innych chorób wpływających na zburzenia połykania (udar mózgu), progresji choroby podstawowej i konieczności dalszych interwencji chirurgicznych lub z powodu braku możliwości wykonania pełnej procedury badania w związku z awarią sprzętu do wideofluoroskopii. Kryteria włączania obejmowały: stan po całkowitym usunięciu krtani; minimum 6 miesięcy od operacji; obecność wskazań klinicznych do wykonania pogłębionej diagnostyki dysfagii ustno-gardłowej (VFSS), stwierdzonych na podstawie oceny foniatrycznej i logopedycznej; wyrażenie przez pacjenta zgody na udział w badaniu. Ostatecznie grupę badaną stanowiło 10 kolejnych pacjentów spełniających kryteria włączenia do badania, zgłaszających się do Poradni Logopedycznej lub Poradni Foniatrycznej Uniwersyteckiego Centrum Klinicznego Warszawskiego Uniwersytetu Medycznego między kwietniem 2017 a czerwcem 2018 roku. Średni wiek badanych wynosił 65,5 \pm 5,3 lat. Najmłodsza osoba miała 56 lat, a najstarsza 75 lat. W badaniu wzięło udział 8 mężczyzn (80\%) oraz 2 kobiety (20\%).

Wszyscy chorzy zostali zbadani zgodnie z jednolitym protokołem: 1) wywiad obejmujący pytania dotyczące: danych biometrycznych (wiek, płeć), sposobu leczenia (chirurgia, radioterapia), typu wytworzonego głosu zastępczego; 2) badanie wideofluoroskopowe z częścią diagnostyczną i terapeutyczną (VFSS); 3) wypełnienie kwestionariusza MDADI (M.D. Aderrson Dysphagia Inventory) metodą "papier-ołówek”.

Badanie VFSS wykonano na aparacie typu Opera, frame rate 3 klatki na sekundę. W części wstępnej oceniano anatomię struktur jamy ustnej i gardła. Następnie pacjenci pobierali $5 \mathrm{ml}$ wody zmieszanej z barytem (w stosunku $1: 1$ ), przytrzymywali ją w ustach i połykali dopiero na polecenie (ocena kontroli oralnej). Później oceniano pobieranie płynu zagęszczonego (woda : baryt $=1: 1$, zagęszczacz Nulilis Clear, 1 miarka na $200 \mathrm{ml}$ płynu) oraz pokarmu stałego (suchar posmarowany 
barytem). Dwie niezależne osoby (foniatra i logopeda), z pięcioletnim doświadczeniem $\mathrm{w}$ przeprowadzaniu i opisywaniu badania VFSS, oceniały następujące parametry: kontakt podstawy języka z tylną ścianą gardła, zaburzenia obróbki oralnej, występowanie ruchów pompujących języka, obecność regurgitacji treści pokarmowych do nosa, obecność skurczu mięśnia pierścienno-gardłowego. Na zakończenie sprawdzano skuteczność manewrów terapeutycznych (por. Jamróz, Chmielewska-Walczak, Milewska, 2019, s. 134-136).

Po zakończeniu badania VFSS pacjenci wypełniali ankietę MDADI. Ankieta służy do oceny jakości życia związanej z zaburzeniami połykania u pacjentów leczonych onkologicznie. Kwestionariusz zawiera 20 pytań, ocenianych w skali 1-5. Minimalnie można uzyskać 0 punktów, maksymalnie - 100. Wyższa liczba punktów świadczy o lepszej jakości życia związanej z zaburzeniami połykania.

Analizy statystycznej dokonano przy użyciu pakietu IBM SPSS Statistics 25. Program został wykorzystany do charakterystyki grupy. W analizie statystycznej wyników wykonano analizę częstości (N; \%). Ze względu na ostatecznie małą liczebność grupy badanej w pracy zastosowano metodę statystyki opisowej.

$\mathrm{Na}$ przeprowadzenie badania uzyskano zgodę Komisji Bioetycznej (AKEB/225/2018). Badania były przeprowadzone w ramach pracy magisterskiej, zatytułowanej tak samo, jak niniejszy artykuł, której autorem jest pierwsza, a promotorem - druga $\mathrm{z}$ autorek artykułu.

\section{Wyniki}

W przypadku większość pacjentów leczenie chirurgiczne było uzupełnione radioterapią $(\mathrm{n}=7 ; 70 \%)$. Głos przełykowy wykształciło 3 pacjentów $(30 \%)$, pozostałe zaś 7 osób (70\%) posługiwało się pseudoszeptem ustno-gardłowym. Dwie osoby miały wszczepioną protezę głosową typu Provox.

Wyniki badania wideofluoroskopowego przedstawiono w tabeli 1 oraz na ilustracjach 1 i 2 . Stwierdzono zaburzenia faz połykania: ustnej (zaburzona obróbka oralna kęsa, ruchy pompujące języka) oraz gardłowej (skurcz mięśnia pierścienno-gardłowego, regurgitacje treści pokarmowych do nosa, zaburzony kontakt nasady języka $z$ tylną ścianą gardła). Wyniki uzyskane w kwestionariuszu MDADI pokazano $\mathrm{w}$ tabeli 2 , zaś porównanie dwóch podgrup wydzielonych na podstawie kryterium zastosowanej metody leczenia (chirurgia $v s$ chirurgia $\mathrm{z}$ uzupełniającą radioterapią) - na wykresie 1. Pacjenci po radioterapii zgłaszali gorszą jakość życia niż osoby bez leczenia uzupełniającego. Dotyczyło to wszystkich sfer życia emocjonalnej, funkcjonalnej, społecznej oraz oceny ogólnej. 
K. Godlewska, B. Jamróz, J. Chmielewska-Walczak, M. Milewska: Ocena...

TABELA 1. Ocena wyników wybranych parametrów badania wideofluoroskopowego

\begin{tabular}{|l|c|c|}
\hline \multicolumn{1}{|c|}{ Parametr badania VFSS } & Patologia [\%] & Norma [\%] \\
\hline Kontakt podstawy języka z tylną ścianą gardła & 100 & - \\
\hline Obróbka oralna kęsa & 90 & 10 \\
\hline Ruchy pompujące języka & 80 & 20 \\
\hline Skurcz mięśnia pierścienno-gardłowego & 60 & 40 \\
\hline Regurgitacje treści pokarmowych do nosa & 30 & 70 \\
\hline
\end{tabular}

ŹRóDŁo: Opracowanie własne.

TABELA 2. Wyniki kwestionariusza MDADI

\begin{tabular}{|l|c|c|c|c|}
\hline \multicolumn{1}{|c|}{ Wartość } & Ogólna ocena & $\begin{array}{c}\text { Zaburzenia } \\
\text { emocjonalne }\end{array}$ & $\begin{array}{c}\text { Zaburzenia } \\
\text { funkcjonalne }\end{array}$ & $\begin{array}{c}\text { Zaburzenia } \\
\text { społeczne }\end{array}$ \\
\hline Średnia \pm SD & $32,0 \pm 21,5$ & $45,7 \pm 14,5$ & $52,5 \pm 12,6$ & $45,4 \pm 9,9$ \\
\hline $\begin{array}{l}\text { Mediana } \\
\text { (min.-maks.) }\end{array}$ & $\begin{array}{c}20 \\
(20-80)\end{array}$ & $\begin{array}{c}41,5 \\
(33-83)\end{array}$ & $\begin{array}{c}48 \\
(40-84)\end{array}$ & $\begin{array}{c}44,5 \\
(25-58)\end{array}$ \\
\hline
\end{tabular}

ŹRóDŁo: Opracowanie własne.

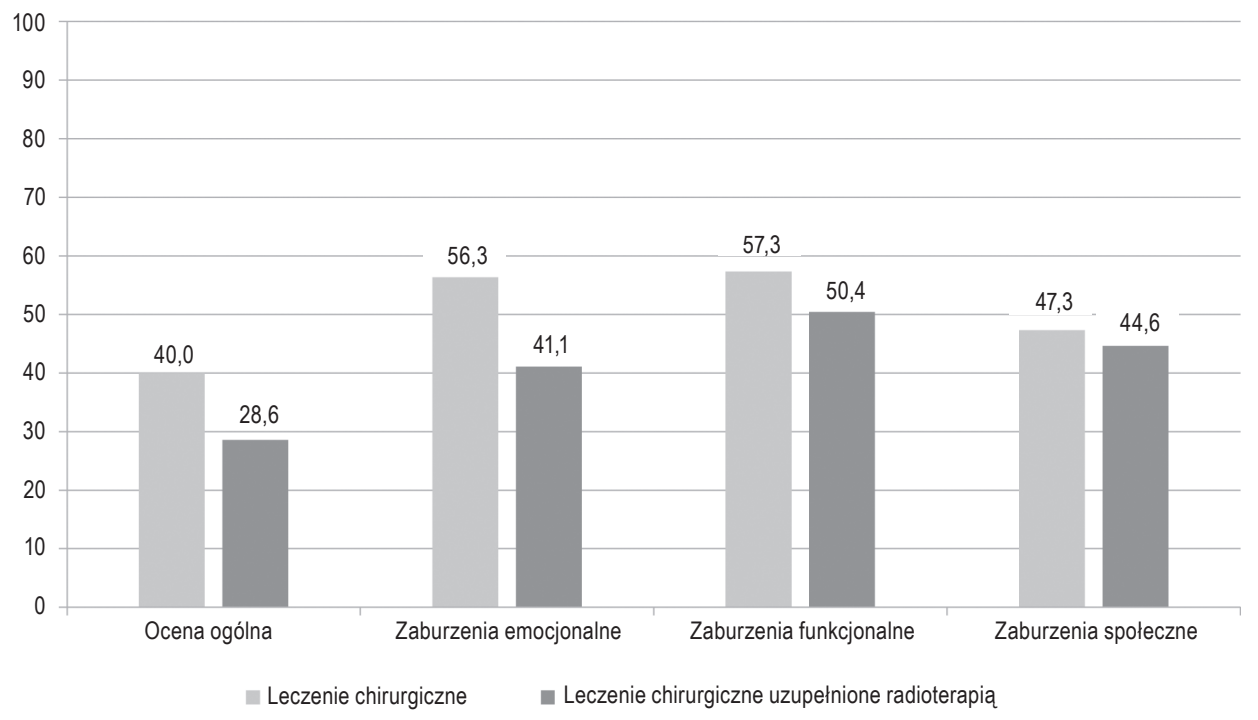

WYKRES 1. Subiektywna ocena jakości życia w grupie badanej w zależności od zastosowanego leczenia (chirurgia $v s$ chirurgia $\mathrm{z}$ uzupełniającą radioterapią)

ŹróDŁo: Opracowanie własne. 


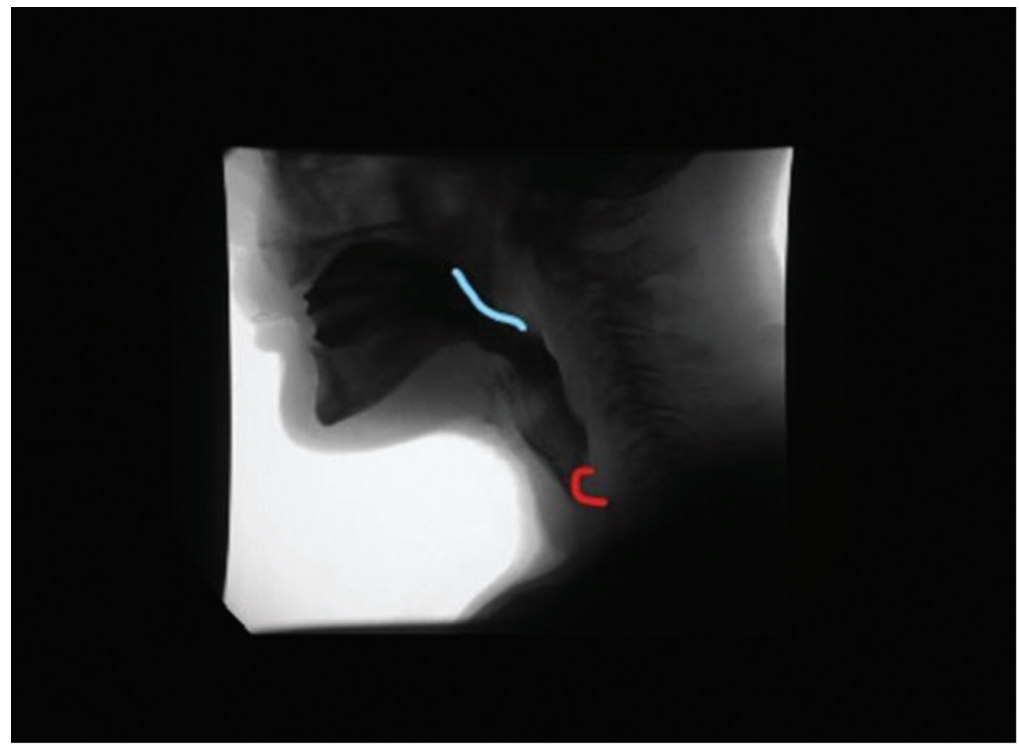

ILUSTRACJA 1. Brak kontaktu języka z tylną ścianą gardła (niebieska linia) oraz skurcz mięśnia pierścienno-gardłowego (czerwona linia)

ŹRóD£o: Materiał z badań własnych. Badanie wykonane w Klinice Otorynolaryngologii, Chirurgii Głowy i Szyi, Warszawski Uniwersytet Medyczny.

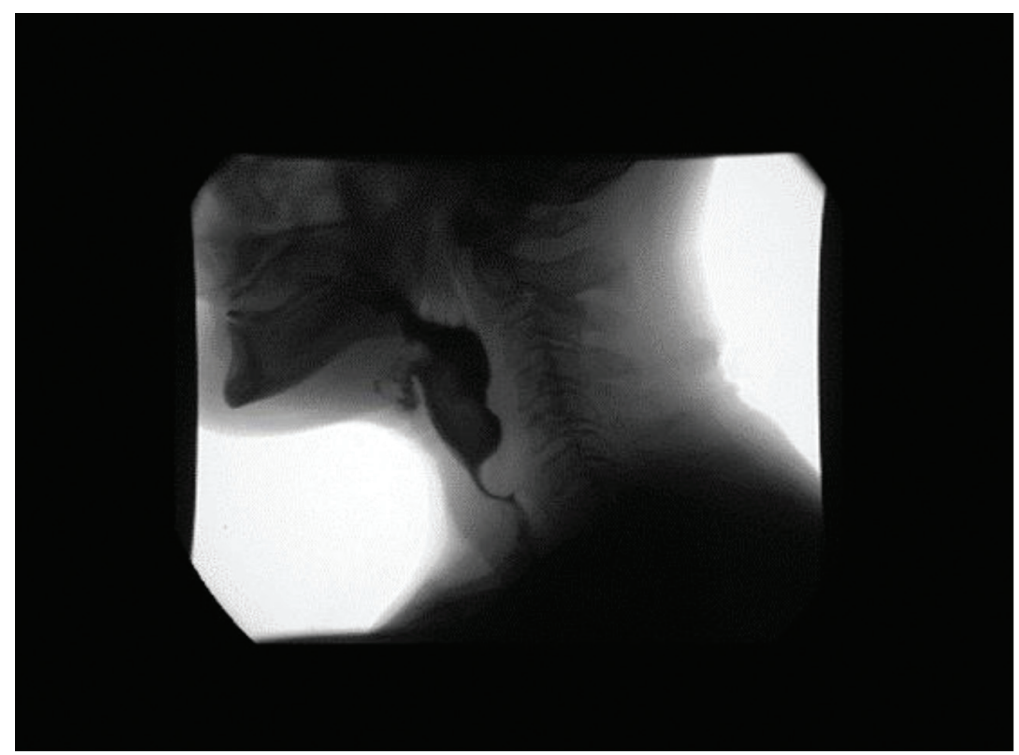

ILUSTRACjA 2. Skurcz mięśnia pierścienno-gardłowego, masywne zalegania nad zwieraczem górnym przełyku, ryzyko regurgitacji treści pokarmowych do nosa

ŹRóDŁo: Materiał z badań własnych. Badanie wykonane w Klinice Otorynolaryngologii, Chirurgii Głowy i Szyi, Warszawski Uniwersytet Medyczny. 
Najwyższe wyniki w ocenie ogólnej uzyskały osoby, u których w VFSS nie stwierdzono skurczu mięśnia pierścienno-gardłowego $(\mathrm{n}=3)$, regurgitacji do nosa $(\mathrm{n}=2)$ i ruchów pompujących języka $(\mathrm{n}=2)$ (najwyższe wyniki w tej części ankiety: $80,60,40)$; dla oceny funkcjonalnej - podobne parametry z badania VFSS okazały się niezaburzone: brak skurczu mięśnia pierścienno-gardłowego $(\mathrm{n}=2)$, regurgitacji do nosa $(\mathrm{n}=3)$ i ruchów pompujących języka $(\mathrm{n}=1)$ (najwyższe wyniki w tej części ankiety: 49, 53, 83); dla oceny funkcjonalnej: brak skurczu mięśnia pierścienno-gardłowego $(\mathrm{n}=2)$, regurgitacji do nosa $(\mathrm{n}=3)$ (najwyższe wyniki w tej części ankiety: 84, 59, 56, 55); zaś dla oceny czynnościowej: brak regurgitacji do nosa $(\mathrm{n}=2)$ i skurczu mięśnia pierścienno-gardłowego $(\mathrm{n}=1)$ (najwyższe wyniki w tej części ankiety: 58, 57, 55). Najważniejszymi parametrami związanymi z lepszą oceną jakości życia okazały się: czynnościowe ukształtowanie na poziomie segmentu gardłowo-przełykowego oraz związana z nim obecność lub brak regurgitacji treści pokarmowych do nosa.

\section{Dyskusja}

Pacjenci po radyklanym usunięciu krtani, już od momentu postawienia diagnozy, muszą mierzyć się z wieloma trudnościami w codziennym życiu. Operacja niesie z sobą poważne konsekwencje, które pozostawiają widoczny ślad w życiu emocjonalnym i funkcjonalnym chorych (Landera i in., 2010, s. 39-44).

Dotyczy to nie tylko sposobu tworzenia głosu zastępczego, lecz także fizjologii połykania. Dlatego bardzo ważną kwestią jest dobór odpowiedniego planu terapeutycznego, z uwzględnieniem aspektów istotnych z punktu widzenia jakości życia.

Dodatkowo, w literaturze przedmiotu, opisuje się związek pomiędzy zastosowaniem radioterapii jako metody uzupełniającej a jakością życia chorych (Hutcheson i in., 2012, s. e5793-e5799). W prezentowanym badaniu 70\% grupy stanowili chorzy, w których przypadku zastosowano tę formę leczenia. Przyczyną zaburzeń połykania u pacjentów po radioterapii mogą być: kserostomia, która negatywnie wpływa na formowanie bolusa oraz transport oralny; nasilony obrzęk i bolesność tkanek miękkich głowy i szyi; mdłości, problemy z uzębieniem, urata apetytu, odwodnienie oraz neuropatia w obrębie włókien aferentych (Terlingen i in., 2018, s. e2733-e 2748; Czerżyńska i in., 2017, s. 53-62; Búa i in., 2018, s. el70e174). W grupie badanej aż $90 \%$ chorych miało problem z obróbką oralną kęsa, a u $80 \%$ chorych występowały ruchy pompujące języka, które mogą wskazywać na problem $z$ wyzwoleniem odruchu do połykania. Lisanne T. Terlingen i współpracownicy (2018, s. e2733-e2748), po przeprowadzeniu metaanalizy, podkreślają 
negatywny wpływ radiochemioterapii adjuwantowej na mechanizm połykania oraz jakość życia chorych po całkowitej laryngektomii. Negatywny wpływ obserwuje się zarówno przed leczeniem zabiegowym, jak i po nim, dotyczy to nawet 89\% pacjentów. Zazwyczaj objawy są bardziej nasilone przy połykaniu pokarmów stałych niż przy połykaniu płynów (uczucie zalegania, konieczność kilkukrotnego połykania, suchości).

Larissa Sweeny i współautorzy (2012, s. e395-e402) podkreślają zaś, że leczenie uzupełniające nie ma wpływu na występowanie skurczu mięśnia pierścienno-gardłowego. Mięsień ten pełni istotną rolę podczas połykania, jako element funkcjonalny zwieracza górnego przełyku (UES), jak również podczas nauki głosu zastępczego, jako element utworzonej pseudogłośni (Landera i in., 2010, s. 39-44). W prezentowanym badaniu, w czasie wideofluoroskopii odnotowano skurcz mięśnia pierścienno-gardłowego u $60 \%$ chorych, a problem z wytworzeniem głosu zastępczego - aż u 70\% chorych, którzy to porozumiewali się za pomocą pseudoszeptu ustno-gardłowego. Dodatkowo zalegania nad UES mogą powodować regurgitacje treści pokarmowej do nosa (dotyczyło to $30 \%$ badanych pacjentów). Terlingen i współautorzy (2018, s. e2733-e2748) wykazali, że skurcz mięśnia pierścienno-gardłowego jest przyczyną zaburzeń połykania u ok. 22-36\% chorych, zaś zwężenie w miejscu segmentu gardłowo-przełykowego - u ok. 15-19\% chorych. Beatriz Arenaz Búa i współautorzy (2018, s. el70-e174 ) także - jako nieliczni - podkreślają znaczenie kompleksu gardłowo-przełykowego zarówno dla wytwarzania głosu zastępczego, jak i dla połykania. Zaburzenia w tym obszarze będą miały wpływ na obie funkcje, o czym często się zapomina w codziennej praktyce lekarskiej i logopedycznej. Autorzy podkreślają, że najczęstszą metodą terapeutyczną w tym wypadku jest endoskopowa dylatacja, aczkolwiek w praktyce wykorzystywane jest też ostrzykiwanie toksyną botulinową (skuteczność: ok. 10-60\%) (Terlingen i in., 2018, s. e2733-e2748; Búa i in., 2018, s. el70-e174). Jak donoszą Patrick L. Stoner i współautorzy (2019, s. el-e9), najwięcej zwężeń obserwuje się w okresie pierwszego roku po laryngektomii - do $80 \%$, a największy problem stanowią te, które wymagają minimum 5 zabiegów dylatacji i obejmują światło poniżej $14 \mathrm{~mm}$.

Badanie VFSS ujawniło zaburzony kontakt nasady języka z tylną ścianą gardła u wszystkich chorych. Zaburzona ruchomość języka może wynikać nie tylko z zakresu samej operacji, lecz także z usztywnienia tkanek po leczenia uzupełniającym. Brak kontaktu nasady języka z tylną ścianą gardła może z kolei być przyczyną trudności z wyzwoleniem odruchu połykania i występowania ruchów pompujących języka (80\% pacjentów w omawianej grupie).

Badanie jakości życia chorych po laryngektomii całkowitej doświadczających zaburzeń połykania pokazało, że ogólna ocena tej jakości jest niska. Średnio pacjenci otrzymali 32,0/100 pkt. Porównywalnie nisko pacjenci ocenili zaburzenia społeczne i emocjonalne. Najlepsze wyniki uzyskali w sferze funkcjonal- 
nej $(52,5 / 100$ pkt). Wyniki te wskazują na bardzo duży problem w funkcjonowaniu pacjentów w życiu codziennym. Zaburzenia w obszarze emocjonalnym, funkcjonalnym i społecznym są konsekwencją radyklanego usunięcia krtani. Może być to przyczyną niskiej samooceny, niechęci do spotkań z bliskimi, ograniczenia kontaktów społecznych (Studzińska, Obrębowski, Wiskirska-Woźnica, Obrębowska, 2012, s. 124-128). Metaanaliza Terlingen i współautorów (2018, s. e2733-e 2748) pozwoliła wykazać, że ważną metodą wspomagającą leczenie chorych jest psychoterapia. Największe korzyści, w pierwszym roku po zabiegu, odnosili pacjenci, którzy uczestniczyli w spotkaniach grup wsparcia "pacjent-pacjent”, mniejsze - w przypadku spotkań „lekarz-pacjent”, a największe problemy zgłaszali chorzy w ogólne nie uczestniczący w terapii. Autorzy podkreślają jednak, że brakuje jednego zwalidowanego kwestionariusza przeznaczonego dla chorych po laryngektomii. Dostępne kwestionariusze (jak np. MDADI, Swallow Quality of Life) zawierają pytania, które nie mogą być uwzględnione w tej grupie chorych, ze względu na zmiany anatomiczne wynikające z zakresu operacji. Autorzy niniejszego opracowania mają podobne spostrzeżenia.

Warto zwrócić uwagę na to, że dysfagia jest jedną z możliwych przyczyn niedożywienia i odwodnienia, powodując niezamierzony spadek masy ciała. Dodatkowo może towarzyszyć jej depresja, wpływając na niską ocenę jakości życia u takich osób (Stręk i in., 2005, s. 142-146). Wyniki kwestionariusza MDADI pokazały, że niżej oceniali swoją jakość życia pacjenci podlegający adiuwantowej radioterapii, co dotyczyło wszystkich sfer życia: emocjonalnej, społecznej i funkcjonalnej. Prawdopodobnie wynika to z nakładania się na siebie zmian popromiennych na zmiany pooperacyjne. Kwestionariusz MDADI jest ankietą wykorzystywaną do oceny jakości życia pacjentów leczonych onkologicznie (Chen i in., 2001, s. e870-e876). Umożliwia monitorowanie zmian przed zastosowaniem technik terapeutycznych. Jego wadą, jednak o drugorzędowym znaczeniu, jest to, że nie wszystkie pytania są adekwatne do sytuacji chorych po laryngektomii całkowitej (np. pytania o kaszel w czasie picia płynów).

Zrozumiałe jest zatem, że pacjenci po radyklanym usunięciu krtani nie będą czuli się w pełni zdrowi, a proces samoakceptacji po przebytej terapii może być długi, ze względu na wiele zmian, które niesie z sobą nie tylko operacja, lecz także leczenie uzupełniające. Chorzy ci wymagają pomocy zespołu wielospecjalistycznego (laryngolog, radioterapeuta, foniatra, logopeda, dietetyk, psycholog). 


\section{Podsumowanie}

Omówione badanie wykazało, że u pacjentów z zaburzeniami połykania po operacji radyklanego usunięcia krtani należy zwrócić uwagę na współwystępowanie problemów związanych z wytworzeniem głosu zastępczego oraz objawów dysfagii. W obliczu prezentowanych wyników rekomendacje Brytyjskiego Towarzystwa Logopedów dotyczące wskazania do wykonania VFSS u chorych po laryngektomii całkowitej wydają się słuszne, co podkreśla Joanna Chmielewska wraz z zespołem badaczy (2017). Wykonanie VFSS pozwoli na ocenę mechanizmu zaburzenia i dobór odpowiedniej metody rehabilitacji oraz monitorowania jej postępów. Dostępny jest już polski kwestionariusz do oceny wideofluoroskopowej dla chorych po całkowitym usunięciu krtani (Jamróz i in., 2019). Warto przy tym zauważyć, że zgłaszane problemy wpływają na obniżenie jakości życia chorych, co koreluje także z wykorzystaną metodą leczenia (terapia skojarzona $v s$ wyłącznie leczenie chirurgicznie).

\section{Bibliografia}

Búa, B.A., Pendletonc, H., Westinb, U., Rydellc, R. (2018). Voice and swallowing after total laryngectomy. Acta Oto-Laryngologica, 138(2), el70-e174.

Chen, A., Frankowski, R., Bishop-Leone, J. (2001). The development and validation of a dysphagia-specific quality of life questionnaire for patients with head and neck cancer. Archives of Otolaryngology-Head \& Neck Surgery, 127, e870-e876.

Chmielewska, J., Jamróz, B., Gibiński, K., Sielska-Badurek, E., Milewska, M., Niemczyk, K. (2017). Badanie wideofluoroskopowe - procedura badania z oceną kwestionariuszową. Polski Przegląd Otorynolaryngologiczny, 6(1), 2-20.

Czerżyńska, M., OrŁow, P., Choromańska, M. (2017). Skutki uboczne radioterapii nowotworów głowy i szyi. Metody leczenia odczynów popromiennych w jamie ustnej. Pediatria i Medycyna Rodzinna, 13(1), 53-62.

Hamerlińska, A., LemańCzyK, M. (2018). Dysfagia nowotworowa w trakcie radioterapii na przykładzie osób po usunięciu krtani - wyniki badań własnych. Neurolingwistyka Praktyczna, 4, 86-103.

Hutcheson, K., i in. (2012). Late dysphagia after radiotherapy-based treatment of head and neck cancer. Cancer, 118(23), e5793-e5799.

Jamróz, B., Chmielewska-Walczak, J., Milewska, M. (2019). Instrumentalne metody badania zaburzeń połykania. Atlas z materiatem wideo. Warszawa: Medyk.

Landera, M.A., Lundy, D., Sullivan, P.A. (2010). Dysphagia after total laryngectomy. American Speech-Language-Hearning Association, 19(2), 39-44. 
Lippert, D., i in. (2016). Preliminary evaluation of functional swallow after total laryngectomy using high-resolution manometry. Annals of Otology, Rhinology \& Laryngology, 125(7), e541-e549.

Manikantan, K., i in. (2009). Dysphagia in head and neck cancer. Cancer Treatment Reviews, 35, e724-e732.

Stoner, P.L., Fullerton, A.L., Freeman, A.M., Chheda, N.N., Estores, D.S. (2019). Endoscopic dilation of refractory postlaryngectomy strictures: A case series and literature review. Gastroenterology Research and Practice, el-e9, https://doi.org/10.1155/2019/8905615.

STRĘK, P., i in. (2003). Ankietowa samoocena zaburzeń połykania i jakość życia u chorych leczonych z powodu nowotworów głowy i szyi. Otorynolaryngologia, 2(3), 120-125.

STRĘK, P., i in. (2005). Jakość życia a dysfagia u chorych po operacji raka krtani. Otorynolaryngologia, 4(3), 142-146.

STRĘK, P., i in. (2006). Wpływ podeszłego wieku na subiektywne oceniane zaburzenia połykania u chorych leczonych z powodu nowotworów głowy i szyi. Gerontologia Polska, 14(1), s. 98-105.

Studzińska, K., Obrębowski, A., Wiskirska-Woźnica, B., Obręвowska, Z. (2012). Problemy psychologiczne w rehabilitacji chorych po operacjach całkowitego usunięcia krtani. Polski Przeglad Otorynolaryngologiczny, 2(1), 124-128.

Sweeny, L., Golden, J.B., White, H.N., Magnuson, J.C., Carroll, W.R., Rosenthal, E.L. (2012). Incidence and outcomes of stricture formation postlaryngectomy. Otolaryngology - Head and Neck Surgery, 146(3), e395-e402.

Terlingen, L.T., Pilz, W., Kuijer, M., Kremer, B., Baijens, L.W. (2018). Diagnosis and treatment of oropharyngeal dysphagia after total laryngectomy with or without pharyngoesophageal reconstruction: Systematic review. Head \& Neck, 40, e2733-e2748.

ZHANG, T., i in. (2016). Biomechanics of pharyngeal deglutitive function following total laryngectomy. Otolaryngology - Head and Neck Surgery, 155(2), e295-e302. 